Eur. J. Clin. Chem. Clin. Biochem.

Vol. 31, 1993, pp. 733-738

(C) 1993 Walter de Gruyter \& Co.

Berlin - New York

\title{
Discrimination Between Periportal and Pericentral Necrosis of Rat Liver by Determination of Glutamine Synthetase and Other Enzyme Activities in Serum
}

\author{
By Sigrid Kress and N. Katz \\ Institut für Klinische Chemie und Pathobiochemie, Universität Gießen, Germany
}

(Received July 28/August 18, 1993)

\begin{abstract}
Summary: Periportal or pericentral necrosis of rat liver was produced by injection of allylalcohol or bromobenzene, respectively. Activities of predominantly periportal and perivenous enzymes were determined in serum during maximal necrosis. Aspartate aminotransferase, which is more or less homogeneously distributed in the liver acinus, exhibited similar activities in serum after periportal and pericentral injury. Serum activities of the mainly periportal enzymes alanine aminotransferase and fructose 1,6-bisphosphatase were 1.5- to 2fold higher after periportal as compared to pericentral necrosis. Serum activity of the mainly pericentral glutamate dehydrogenase was 3 -fold higher after pericentral than after periportal damage. However, due to individual variations necrosis could not be definitively localized in any case by measurement of these enzyme activities. Better discrimination between periportal and pericentral necrosis was achieved by the serum activity of the exclusively pericentral enzyme glutamine synthetase, which was 8-fold higher after pericentral as compared to periportal necrosis. Conclusive discrimination was obtained by the activity ratio fructose $1,6-$ bisphosphatase/glutamine synthetase in serum.
\end{abstract}

\section{Introduction}

Many enzymes are heterogeneously distributed along the sinusoids of the liver acinus. Thus, periportal and pericentral ( = perivenous) liver cells present different patterns of enzyme activity: enzymes involved in gluconeogenesis, amino acid degradation and urea synthesis exhibit higher activity in periportal hepatocytes $(1-2)$; enzymes involved in glycolysis, xenobiotic metabolism and glutamine synthesis exhibit higher activity in percentral hepatocytes $(3-5)$. This distribution led to the concept of metabolic zonation of the liver acinus $(6-8)$.

Liver injury by infectious diseases or by congestion is often not homogeneously distributed throughout the acinus. After cardiac failure alterations are observed mainly in the pericentral zone with central to central bridging necroses. On the other hand, during chronic aggressive hepatitis typical piecemeal necrosis is pre- dominantly localized in the periportal zone (9). Moreover, selective injury of periportal or pericentral hepatocytes is seen after intoxication with various agents. Administration of phosphorus or of allylalcohol results in a periportal destruction, whereas intoxication with halogenated hydrocarbons results in pericentral necrosis (4).

Information on the zonal localization of liver necrosis may help in recognizing the pathological mechanism of an injury. In principle, liver biopsy yields this information, but in the acute phase of severe injury it may be contraindicated. Due to the intra-acinar heterogeneity of enzyme activities, different patterns of hepatic enzymes should occur in serum after periportal and after pericentral necrosis. In previous studies glutamate dehydrogenase (10) and fructose 1,6bisphosphatase activities $(9,11)$ were determined in human serum, to localize liver necrosis. 
It was the aim of the present study to improve the diagnosis of liver necrosis by measurement of enzyme activities in serum after selective zonal injury in rats. The serum activities of glutamine synthetase and of other heterogeneously distributed liver enzymes allowed the prediction of the localization of necrosis within the liver acinus.

\section{Materials and Methods}

\section{Materials}

Enzymes, coenzymes and substrates were purchased from Boehringer (Mannheim, Germany). Allylalcohol was supplied by Fluka (Buchs, $\mathrm{CH}$ ); All other chemicals were obtained from Merck (Darmstadt, Germany).

\section{Treatment of animals}

Wistar rats $(160-240 \mathrm{~g})$ were maintained on a $12 \mathrm{~h}$ day/night rhythm and fed a standard diet (Altromin, Lage, Germany) ad libitum. Periportal necrosis was produced by intraperitoneal injection of two doses of $0.62 \mathrm{mmol}$ allylalcohol dissolved in $9 \mathrm{~g} / \mathrm{l} \mathrm{NaCl}$ per $\mathrm{kg}$ body weight at $8 \mathrm{a} . \mathrm{m}$. and $8 \mathrm{p}$. m. Pericentral necrosis was produced by intraperitoneal injection of $3.8 \mathrm{mmol}$ bromobenzene dissolved in vegetable oil per $\mathrm{kg}$ body weight at 8 a.m. Control animals received injections of $9 \mathrm{~g} / \mathrm{l} \mathrm{NaCl}$ or vegetable oil. Blood was collected from the abdominal vena cava during anesthesia with sodium pentobarbital $(60 \mathrm{mg}$ per $\mathrm{kg}$ body weight). Serum was obtained after clotting for $20 \mathrm{~min}$ by centrifugation at $3000 \mathrm{~g}$ for $15 \mathrm{~min}$ at $4^{\circ} \mathrm{C}$; haemolytic sera were excluded from the study. After collection of blood the livers were removed and frozen in liquid nitrogen for histological examination using the hematoxyline-eosine staining technique.

\section{Enzyme assays}

Fructose 1,6-bisphosphatase activity was determined according to Latzko \& Gibbs (12) with slight modification using the following test solution: Tris/ $\mathrm{HCl} 50 \mathrm{mmol} / \mathrm{l}(\mathrm{pH} 7.5)$, EDTA $0.1 \mathrm{mmol} / \mathrm{l}, \mathrm{MgSO}_{4} 5 \mathrm{mmol} / \mathrm{l}, \beta$-mercaptoethanol $2 \mathrm{mmol} / \mathrm{l}$, $\mathrm{NADP}^{+} 0.2 \mathrm{mmol} / \mathrm{l}$, phosphoglucose isomerase $0.2 \mathrm{kU} / \mathrm{l}$, glucose 6-phosphate dehydrogenase $0.1 \mathrm{kU} / \mathrm{l}$. The specific reaction was started by addition of fructose 1,6-bisphosphate $0.1 \mathrm{mmol} / \mathrm{l}$. More than $85 \%$ of the activity measured under this condition was blocked by the presence of AMP $0.1 \mathrm{mmol} / \mathrm{l}$, a specific inhibitor of fructose 1,6-bisphosphatase (11), indicating that essentially alkaline phosphatase did not disturb the test.

For determination of the glutamine synthetase activity $50 \mu \mathrm{l}$ serum was incubated with $250 \mu$ l of the following test solution: imidazole $/ \mathrm{HCl} 50 \mathrm{mmol} / \mathrm{l}(\mathrm{pH} 6.8), L$-glutamine $50 \mathrm{mmol} / \mathrm{l}$, hydroxylamine $25 \mathrm{mmol} / \mathrm{l}$, sodium arsenate $25 \mathrm{mmol} / \mathrm{l}$, ADP $0.16 \mathrm{mmol} / \mathrm{l}$ and $\mathrm{MnCl}_{2} 2 \mathrm{mmol} / \mathrm{l}$ (13). After $30 \mathrm{~min}$ the reaction was stopped by addition of $500 \mu \mathrm{FeCl}_{3} 90 \mathrm{mmol} / \mathrm{l}$, trichloroacetic acid $0.5 \mathrm{~mol} / \mathrm{l}$ and $\mathrm{HCl} 1.82 \mathrm{~mol} / \mathrm{l}$; denatured proteins were removed by centrifugation and the supernatant was measured photometrically at $544 \mathrm{~nm}$ against a blank without serum. For calibration $300 \mu \mathrm{l}$ glutamylhydroxamate was mixed with $500 \mu \mathrm{l}$ of stop solution and absorption was measured at final concentrations between 0.1 and $1 \mathrm{mmol} / \mathrm{l}$. The activities of alanine aminotransferase and aspartate aminotransferase were determined according to the suggestion of the German Society for Clinical Chemistry (14) with test solutions supplied by Boehringer (Mannheim, Germany) using a Hitachi 717 analyzer. Glutamate dehydrogenase activity was tested according to Schmidt (15) with reagent from Boehringer (Mannheim,
Germany) using an Eppendorf EPOS analyzer. All activities were determined at $37^{\circ} \mathrm{C}$. Serum was diluted with $9 \cdot \mathrm{g} / \mathrm{l} \mathrm{NaCl}$, if necessary.

The statistical evaluation was performed using the Student ttest for unpaired data.

\section{Results}

Administration of allylalcohol to adult rats resulted in distinct periportal necrosis of liver tissue. However, the extent and intensity of the cellular damage was subject to individual variation: some animals exhibited only minor alteration of the hepatocellular morphology, while other animals showed severe necrosis. The maximal morphological alteration was observed $24 \mathrm{~h}$ after the first intraperitoneal injection of the poison. Simultaneously a maximal activity of hepatic enzymes was detected in serum. The histological inspection of liver tissue demonstrated that in six rats (No 1-6) liver necrosis was restricted to the periportal zone; in two animals (No 7-8) the adjacent part of the pericentral zone was impaired, too. On the other hand, the administration of bromobenzene led to a predominant necrosis of pericentral tissue. Maximal alteration of the hepatocellular morphology was observed $48 \mathrm{~h}$ after administration of the poison, which coincided with maximal activity of hepatic enzymes in serum. Bromobenzene-dependent necrosis was restricted to the pericentral zone in six animals (No 11-16); in two rats an additional but minor alteration of periportal tissue occurred (No 17-18).

The activities of hepatocellular enzymes were increased in serum within one and two days after injection of allylalcohol and bromobenzene, respectively. For comparison of the periportal and pericentral injuries the enzyme activities in serum were studied during the maximum of necrosis $24 \mathrm{~h}$ after administration of allylalcohol and $48 \mathrm{~h}$ after administration of bromobenzene (fig. 1). The activity of aspartate aminotransferase, which is nearly homogeneously distributed throughout the liver acinus, was about 40fold increased in serum of animals with periportal as well as in serum of animals with pericentral necrosis. In contrast, the activity of alanine aminotransferase and of fructose 1,6-bisphosphatase, which are twofold higher in periportal than in pericentral tissue, exhibited a 40 -fold increase in serum after periportal necrosis but only a 30 - and 20 -fold increase, respectively, after pericentral necrosis. The activity of glutamate dehydrogenase, which is about two-fold higher in pericentral than in periportal tissue, was increased in serum 120-fold during periportal injury but 360 fold during pericentral damage. Glutamine synthetase activity, which is localized exclusively in a few hepa- 


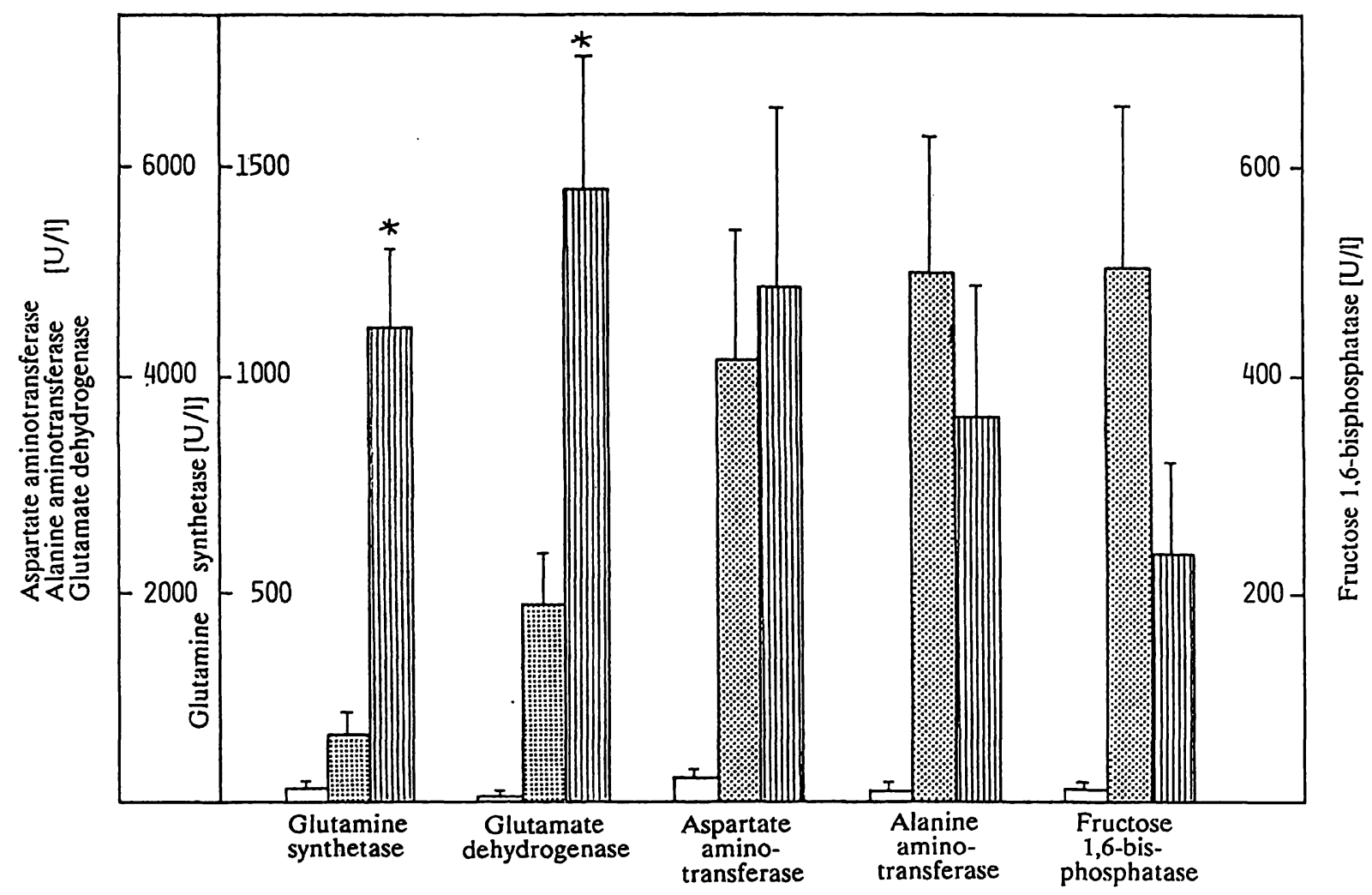

Fig. 1. Activity of hepatic enzymes in serum. Enzyme activities were determined $24 \mathrm{~h}$ after the administration of allylalcohol to produce periportal necrosis (国), and $48 \mathrm{~h}$ after administration of bromobenzene to produce pericentral necrosis (四), as well as in untreated rats $(\square)$. At this time maximal hepatocellular destruction and maximal enzyme activity in serum were observed. Means \pm SEM are given; each group represents 8 animals. Significant differences between periportal and pericentral necrosis are indicated by asterisks $(p<0.02)$.

tocytes around the central vein, was enhanced in serum 5-fold during periportal but 40 -fold during pericentral necrosis. The differences due to the pericentral enzymes were statistically significant.

The magnitude of hepatic enzyme activities in serum is not only influenced by the zonal heterogeneity but also by the extent of the liver injury. In order to compensate for this influence, ratios between serum activities of periportal and pericentral marker enzymes were considered (tab. 1). The ratio aspartate aminotransferase + alanine aminotransferase/glutamate dehydrogenase was suggested by Schmidt \& Schmidt (16) to discriminate acute hepatitis, chronic hepatitis and cholestatic liver diseases in man. In the present study this ratio was higher during periportal necrosis $(6.3 \pm 4.9)$ than during pericentral necrosis $(1.5 \pm 0.8)$. More pronounced differences were presented by the ratio aspartate aminotransferase + alanine aminotransferase/glutamine synthetase, which was $72.8 \pm 32.4$ during periportal and $9.0 \pm 11.1$ during pericentral injury, as well as by the ratio alanine aminotransferase/glutamine synthetase, which was $42.2 \pm 26.3$ during periportal and $4.0 \pm 5.1$ during pericentral damage. The best discrimination was achieved by calculation of the ratio fructose 1,6bisphosphatase/glutamine synthetase, which was 4.2 \pm 2.7 during periportal but $0.23 \pm 0.28$ during pericentral necrosis. Using this ratio it was possible to predict the predominant localization of a hepatocellular injury, even if the damage was not entirely restricted to the periportal or to the pericentral zone.

\section{Discussion}

In contrast to the uniform light microscopical morphology of hepatocytes, biochemical heterogeneity exists between periportal and pericentral liver cells. At first, histochemical studies demonstrated that key enzymes of metabolic pathways exhibit different activities in periportal and pericentral hepatocytes (17). In contrast to the discontinuous functional heterogeneity along the kidney nephron (18), the activity of most hepatic enzymes is continuously increased or decreased along the sinusoids. Thus, periportal to pericentral gradients of enzyme activities mostly range between 0.2 and 5. Exclusively, the expression of glutamine synthetase is restricted to a few hepatocytes around the central vein (19).

Besides histochemical and microbiochemical analyses, the heterogeneous localization was demonstrated by selective zonal destruction using digitonin or other 
Tab. 1. Ratios of enzyme activities in serum after periportal and pericentral necrosis of rat liver.

\begin{tabular}{|c|c|c|c|c|c|}
\hline \multirow[t]{3}{*}{ Necrosis } & \multirow[t]{3}{*}{ Rat } & \multirow{3}{*}{$\begin{array}{l}\text { Aspartate } \\
\text { aminotransferase } \\
+ \text { Alanine } \\
\text { aminotransferase } \\
\begin{array}{l}\text { Glutamate } \\
\text { dehydrogenase }\end{array}\end{array}$} & \multirow{3}{*}{$\begin{array}{l}\text { Aspartate } \\
\text { aminotransferase } \\
+ \text { Alanine } \\
\text { aminotransferase } \\
\begin{array}{l}\text { Glutamine } \\
\text { synthetase }\end{array}\end{array}$} & \multirow{3}{*}{$\begin{array}{l}\begin{array}{l}\text { Alanine } \\
\text { aminotransferase }\end{array} \\
\text { Glutamine } \\
\text { synthetase } \cdot \text { t }\end{array}$} & \multirow{3}{*}{$\begin{array}{l}\begin{array}{l}\text { Fructose } \\
\text { 1,6-bis- } \\
\text { phosphatase }\end{array} \\
\begin{array}{l}\text { Glutamine } \\
\text { synthetase }\end{array}\end{array}$} \\
\hline & & & & & \\
\hline & & & & & \\
\hline Periportal & $\begin{array}{l}1 \\
2 \\
3 \\
4 \\
5 \\
7 \\
7^{*} \\
8^{*} \\
\bar{x} \pm S D\end{array}$ & $\begin{array}{r}2.4 \\
5.8 \\
8.7 \\
6.8 \\
3.5 \\
4.1 \\
2.1 \\
17.1 \\
6.3 \pm 4.9\end{array}$ & $\begin{array}{r}44.0 \\
83.9 \\
42.2 \\
64.8 \\
76.7 \\
93.1 \\
32.1 \\
134.9 \\
72.8 \pm 32.4\end{array}$ & $\begin{array}{l}21.2 \\
38.8 \\
27.2 \\
40.2 \\
44.2 \\
58.6 \\
11.1 \\
96.2 \\
42.2 \pm 26.3\end{array}$ & $\begin{array}{l}2.1 \\
5.26 \\
3.22 \\
3.12 \\
1.75 \\
7.14 \\
1.96 \\
9.09 \\
4.21 \pm 2.70\end{array}$ \\
\hline Pericentral & $\begin{array}{l}11 \\
12 \\
13 \\
14 \\
15 \\
16 \\
17^{*} \\
18^{*} \\
\bar{x} \pm S D\end{array}$ & $\begin{array}{l}0.8 \\
1.0 \\
0.6 \\
1.2 \\
2.0 \\
1.3 \\
2.0 \\
2.9 \\
1.5 \pm 0.8\end{array}$ & $\begin{array}{r}4.0 \\
4.1 \\
3.6 \\
1.5 \\
3.7 \\
1.0 \\
26.9 \\
26.8 \\
9.0 \pm 11.1\end{array}$ & $\begin{array}{l}2.0 \\
2.1 \\
0.9 \\
1.5 \\
0.1 \\
0.4 \\
12.4 \\
12.1 \\
4.0 \pm 5.1\end{array}$ & $\begin{array}{l}0.18 \\
0.08 \\
0.19 \\
0.08 \\
0.08 \\
0.06 \\
0.32 \\
0.90 \\
0.23 \pm 0.28\end{array}$ \\
\hline
\end{tabular}

All differences between periportal and pericentral necrosis were statistically significant $(p<0.02)$.

* Necrosis was not restricted to the predominantly damaged zone.

poisons. Perfusion of rat liver with digitonin in the orthograde direction results in a periportal necrosis, while perfusion in the reverse direction results in a pericentral necrosis. The zonal localization of enzymes in vivo was concluded from their release into the perfusion medium during selective zonal damage $(20$, 21).

Reciprocally it should be possible to predict the intrahepatic localization of a zonal damage by determination of enzyme activities in serum. Periportal hepatocytes can be selectively injured by injection of allylalcohol (22). However, a conclusive answer as to the mechanism of its zonal selective toxicity is still lacking. Apparently, the mitochondrial respiration is uncoupled by acrolein (23), which is formed from allylalcohol predominantly in the periportal zone (24). This might be due to the extremely high first path uptake by periportal hepatocytes rather than to the slight periportal predominance of allylalcohol metabolizing alcohol dehydrogenase (25). In the present study, allylalcohol-dependent necrosis was restricted to the periportal zone in six of eight animals. On the other hand, pericentral hepatocytes are selectively destroyed by halogenated organic compounds such as carbon tetrachloride or bromobenzene. The zonal specificity of the toxic effect is apparently due to the formation of electropholic products by cytochrome $\mathrm{P}_{450}$ enzymes, which exhibit higher activity in the pericentral tissue (4). Moreover, the protection against electrophilic metabolites by glutathione is lower in pericentral than in periportal hepatocytes, resulting in lipid peroxidation predominantly in the pericentral zone (4). In the present study six of eight animals showed morphological alterations exclusively in pericentral tissue after administration of bromobenzene.

The activity of the mainly periportal enzyme fructose 1,6-bisphosphatase in serum was previously introduced in the discrimination between chronic aggressive and chronic persistent hepatitis in man due to zonal differences of cell necrosis (9). Relatively high activity of the enzyme correlated with the mainly periportal piecemeal necrosis during chronic aggressive liver disease. Nevertheless, a definite discrimination could not be achieved.

Another study described the differentiation between central liver necrosis after cardiac failure and acute viral hepatitis by determination of aminotransferases and glutamate dehydrogenase in buman serum (10). However, the 40-fold higher activity of glutamate dehydrogenase activity after central necrosis versus acute hepatitis could not be explained by the approximately two-fold higher activity of the mitochondrial enzyme in pericentral compared to periportal tissue. Probably this difference wasi predominantly due to extensive necrosis during cardiac failure in compari- 
son to less severe injury during viral hepatitis. As mentioned above, the magnitude of enzyme release into the blood is not only dependent on the zonal heterogeneity of enzymes and toxicity, but depends also on the number of impaired cells and the degree of impairment at the cellular level. Moderate injury of cells results in the release of cytosolic enzymes, while severe intoxication results in the complete destruction of the cell followed by the release of cytosolic as well as of mitochondrial enzymes.

In the present study, the mean extent of periportal and pericentral necrosis was similar as evidenced by the release of aspartate aminotransferase, a mitochondrial and cytosolic enzyme that exhibits a nearly homogeneous distribution in the liver acinus (26). However, remarkable individual differences in the extent of enzyme release existed in both groups. Therefore, it was not possible to predict a periportal necrosis from high serum activity of mainly periportal enzymes. Exclusively, glutamine synthetase activity in serum discriminated in 15 of 16 animals correctly between pericentral and periportal injury.

The influence of size and intensity of the necrosis could be largely reduced by formation of activity ratios in serum of mainly periportal to pericentral enzymes. In any case, conclusive discrimination between periportal and pericentral necrosis was achieved by the ratio fructose 1,6-bisphosphatase/glutamine synthetase. Therefore, this ratio can be regarded as a reliable indicator of the zonal localization of liver necrosis in rats. Further studies will be necessary to establish whether this is also true in man.

\section{Acknowledgement}

We thank Dr. Bohle, Institute of Pathology at the University Hospital, for the examination of histological sections. The skilful technical assistance of Mrs. Klapettek is gratefully acknowledged.

\section{References}

1. Jungermann, K. (1985) Metabolische Zonierung des Leberparenchyms: Bedeutung für die Regulation des Glucostaten Leber. Naturwissenschaften 72, 76-84.

2. Häussinger, D. (1990) Nitrogen metabolism in liver: Structural and functional organization and physiological relevance. Biochem. J. 267, 281-290.

3. Jungermann, K. \& Katz, N. (1989) Functional specialization of different hepatocyte populations. Physiol. Rev. 69, $708-764$.

4. Thurman, R. G., Kauffman, F. C. \& Baron, J. (1986) Biotransformation and zonal toxicity. In: Regulation of Hepatic Metabolism (Thurman, R. G., Kauffman, F. C. \& Jungermann, K., eds.) pp. 321-382, Plenum Press, New York.

5. Gebhardt, R. \& Mecke, D. (1983) Heterogeneous distribution of glutamine synthetase among rat liver parenchymal cells in situ and in primary culture. EMBO J. 2, 567570.

6. Sasse, D., Katz, N. \& Jungermann, K. (1975) Functional heterogeneity of rat liver parenchyma and of isolated hepatocytes. FEBS Lett. 57, 83-88.

7. Katz, N. \& Jungermann, K. (1993) Metabolic heterogeneity of the liver. In: Hepatic Transport and Bile Secretion (Tavoloni, N. \& Berk, P. A., eds.) pp. 55-70, Ravens Press, New York

8. Gumucio, J. J. (1989) Hepatocyte heterogeneity: The coming of age from the description of a biological curiosity to a partial understanding of its physiological meaning and regulation: Hepatology 9, 154-160.

9. Von Rechenberg, H., Fister, P., Eigenbrodt, E., Matthes, K. J. \& Róka, L. (1984) Fructose 1,6-bisphosphatase in the diagnosis of chronic hepatitis II. Clin. Chim. Acta 137, $263-272$.

10. Guder, W. G., Habicht, A., Kleißel, J., Schmidt, U. \& Wieland, O. H. (1975) The diagnostic significance of liver cell inhomogeneity. Z. Klin. Chem. Klin. Biochem. 13, $311-318$.

11. Von Rechenberg, H., Fister, P., Eigenbrodt, E., Matthes, K. J. \& Róka, L. (1984) Fructose 1,6-bisphosphatase in the diagnosis of chronic hepatitis I. Clin. Chim. Acta 137, 255262.
12. Latzko, E. \& Gibbs, N. (1974) Alkalische $C_{1}$-Fructose 1,6diphosphatase. In: Methoden der enzymatischen Analyse (Bergmeyer, H. U., ed.) pp. 914-917, Verlag Chemie, Weinheim.

13. Deuel, T. F., Louie, M. \& Lerner, A. (1978) Glutamine synthetase from rat liver. J. Biol. Chem. 253, 6111-6118.

14. German Society for Clinical Chemistry (1972) Standardization of methods for the estimation of enzyme activities in biological fluids. Z. Klin. Chem. Klin. Biochem. 10, $182-192$.

15. Schmidt, E. (1974) Glutamate dehydrogenase. In: Methoden der enzymatischen Analyse (Bergmeyer, H. U., ed.) pp. 689-696, Verlag Chemie, Weinheim.

16. Schmidt, E. \& Schmidt, F. W. (1988) Glutamate dehydrogenase: Biochemical and clinical aspects of an interesting enzyme. Clin. Chim. Acta 43, 43-56.

17. Wachstein, M. \& Meisel, E. (1956) On the histochemical demonstration of glucose 6-phosphatase. J. Histochem. Cytochem. 4, 592.

18. Ross, B. D. \& Guder, W. G. (1982) Heterogeneity and compartmentation in the kidney. In: Metabolic Compartmentation (Sies, H., ed.) pp. 363-409, Academic Press, London.

19. Gebhardt, R., Ebert, A. \& Bauer, G. (1988) Heterogeneous expression of glutamine synthetase mRNA in rat liver parenchyma revealed by in situ hybridization and Northern. blot analysis of RNA from periportal and perivenous hepatocytes. FEBS Lett. 241, 89-93.

20. Quistorff, B., Grunnet, N. \& Cornell, N. W. (1985) Digitonin perfusion of rat liver. A new approach in the study of intraacinar and intracellular compartmention in the liver. Biochem. J. 226, 289-291.

21. Evans, J. L., Quistorff, B. \& Witters, L. A. (1990) Hepatic zonation of acetyl-CoA carboxylase activity. Biochem. J. $270,665-672$.

22. Nostrant, T. T., Miller, D. L., Appelman, H. D. \& Gumucio, J. J. (1979) Acinar distribution of liver cell regeneration after selective zonal injury in the rat. Gastroenterology 75, $181-186$.

23. Rees, K. R. \& Tarlow, M. J. (1967) The hepatotoxic action of allyl formate. Biochem. J. 104, 757-761. 
24. Belinsky, S. A., Bradford, B. U., Forman, D. T., Glassman, E. B., Felder, M. R. \& Thurman, R. G. (1985) Hepatotoxicity due to allyl alcohol in deermice depends on alcohol dehydrogenase. Hepatology 5, 1179-1182.

25. Maly, I. P., Sasse, D. \& Arnold, M. (1990) Periportal necrosis of liver parenchym after allylalcohol - why? $Z$. Gastroenterol. 28, 41-42.
26. Shank, R. E., Morrison, G., Cheng, H. C., Karl, I. \& Schwartz, R. (1959) Cell heterogeneity within the hepatic lobule. J. Histochem. Cytochem. 7, 237-239.

Prof. Dr. Norbert Katz

Institut für Klinische :Çhemie

und Pathobiochemie

Universität Gießen

Gaffkystraße 11

D-35392 Gießen

Germany 